\title{
Comparison of Intravenous Lignocaine and Dexmedetomidine for Prevention of Propofol Injection Pain
}

\author{
Akoijam Nikhil Singh ${ }^{1}$, Amol P. Singam² \\ 1,2 Department of Anaesthesia, Jawaharlal Nehru Medical College, Datta Meghe \\ Institute of Medical Sciences, Sawangi, Wardha, Maharashtra, India.
}

\section{ABSTRACT}

\section{BACKGROUND}

This study was conducted to compare and evaluate the efficacy and safety of prior intravenous dexmedetomidine with intravenous lignocaine as pre-treatment for prevention of propofol injection pain.

\section{METHODS}

In this prospective, randomised and double blinded clinical study, a total of 200 patients aged between 18 and 70 years of American Society of Anaesthesiologists (ASA) grade I or II posted for elective surgery under general anaesthesia utilising propofol as the inducing agent, were randomly allocated into two groups of 100 patients each, using computer generated random number tables. Group I received intravenous lignocaine $0.2 \mathrm{mg} / \mathrm{Kg}$ and group II received intravenous dexmedetomidine $0.5 \mathrm{mcg} / \mathrm{Kg}$ respectively prior to administration of propofol (2 $\mathrm{mg} / \mathrm{Kg}$ ) for induction during general anaesthesia. Pain during propofol administration was assessed for each patient using the McCririck and Hunter scale. Peri-operative haemodynamic changes and side effects were noted. Data was analysed using chi-square test and a P-value $<0.05$ was considered to be statistically significant.

\section{RESULTS}

A total of 200 patients (100 patients in lignocaine group and 100 patients in dexmedetomidine group) were studied. Statistically significant $(\mathrm{P}<0.05)$ diminution in pain score was discovered to be higher in group II (dexmedetomidine) as compared to group I (lignocaine). $80 \%$ in the dexmedetomidine group had no pain compared to $62 \%$ of the patients in the lignocaine group which is statistically significant. Dexmedetomidine also had a more remarkable effect on the heart rate $(10$ minutes after intubation) compared to lignocaine, with $\mathrm{P}=0.054$ which is statistically significant.

\section{CONCLUSIONS}

Intravenous dexmedetomidine is a superior pre-medication compared to intravenous lignocaine in the prevention of pain following propofol administration. It also has additional properties of sedation, analgesia, anxiolysis and sympatholytic action making it a better alternative for the anaesthesiologist and the patient.

\section{KEY WORDS}

Analgesia, Anxiolysis, Pre-Treatment, General Anaesthesia, Sedation, Sympatholytic Action
Corresponding Author: Dr. Amol P. Singam, Department of Anaesthesia, Jawaharlal Nehru Medical College, Datta Meghe Institute of Medical Sciences, Sawangi, Wardha, Maharashtra, India.

E-mail: draknikhilsingh4773@gmail.com

DOI: $10.14260 / j e m d s / 2021 / 202$

How to Cite This Article:

Singh AN, Singam AP. Comparison of intravenous lignocaine and dexmedetomidine for prevention of propofol injection pain. J Evolution Med Dent Sci 2021;10(13):935-940, DOI: 10.14260/jemds/2021/202

Submission 11-11-2020,

Peer Review 26-01-2021,

Acceptance 04-02-2021,

Published 29-03-2021.

Copyright (C) 2021 Akoijam Nikhil Singh et al. This is an open access article distributed under Creative Commons Attribution License [Attribution 4.0 International (CC BY 4.0)] 


\section{BACKGROUND}

Pain is an unpleasant sensation which is very distressing to the patient. In 1979, the International Association for the Study of Pain (IASP) characterised pain as an "unpleasant sensory and emotional experience associated with actual or potential tissue damage or described in terms of such damage." This definition highlights pain as a confusing experience with various elements.

Propofol (2, 6-di-diisopropylphenol) is a powerful hypnotic, short acting intravenous agent with quick onset of activity and is broadly utilised in enlistment of sedation considering its favourable properties including smooth induction and quick recovery, consequently replacing sodium thiopental. In sub-anaesthetic doses, it displays anti-emetic and anti- pruritic characteristics. The disadvantage of propofol is pain following its injection with incidence between $24 \%$ $70 \% .1,2$ It is positioned seventh, based on difficulty, recurrence and clinical significances faced by an anaesthesiologist during general anaesthesia. ${ }^{3}$

Pain following propofol injection might be immediate or late. Immediate pain is a consequence of the irritant impact of the aqueous phase phenol on the vein, ${ }^{4}$ while late pain is due to the activation of the kallikrein-kinin system which results in bradykinin release. ${ }^{5}$ The lipid solvent of propofol enacts the plasma kallikrein-kinin system and produce bradykinin which alters the peripheral vein by causing vasodilatation and enhanced permeability. This alteration exposes the sensitive nerve endings present in the walls of the blood vessels to the aqueous phase of propofol, bringing about irritation and pain. Lignocaine prevents propofol initiated pain by inhibiting the production of bradykinin. ${ }^{6}$

An ongoing report has proposed that non-particular ligand-gated cation channels including transient receptor potential (TRP) ankyrin 1 (TRPA1) and TRP vanilloid 1(TRPV1) are the major receptors mediating the arousal of peripheral nerve endings by general anaesthetics. ${ }^{7}$ TRPA1 is a particle channel situated on plasma membrane and is delicate to irritants, pain, cold and stretch. Fischer et al. carried out an examination on human and mouse TRPA1 using propofol and inferred that TRPA1 and TRPV1 are the fundamental mediators of propofol injection pain. ${ }^{8}$

A few mediations have been researched to mitigate the pain related with propofol injection by prior administration of opioids, $, 9,10$ acetaminophen, ${ }^{11}$ ondensetron, ${ }^{4}$ tramadol, ${ }^{12}$ ketamine, ${ }^{13}$ thiopental,14,15 metoclopramide, 16 ephedrine, ${ }^{17}$ dexmedetomidine, $18,19,20,21,22$ cold saline, ${ }^{23}$ determination of an enormous vein, for example, antecubital vein, ${ }^{5}$ pre-treatment with lignocaine, $24,25,26,27$ various dosages of lignocaine, 28 distinctive grouping of propofol, ${ }^{29}$ cooling, ${ }^{30}$ weakening of propofol $^{31}$ and effective nitroglycerin. ${ }^{32}$ Among the medications, intravenous lignocaine is the most commonly used medication, yet it has failure rate of $13 \%$ to $32 \% .33,34$

When blended with propofol, lignocaine was more successful in decreasing pain $(\mathrm{P}<0.001)$ than when given as pretreatment. ${ }^{35}$ No relevant chemical destabilisation of the propofol emulsion was observed when it was blended with lignocaine. ${ }^{36}$ It was noted that $0.5 \%$ intravenous (i.v) lignocaine was as effective as $2 \%$ i.v lignocaine in diminishing propofol injection pain when given in various concentrations and dosages of lignocaine, as $1 \mathrm{ml}$ and $2 \mathrm{ml}$ of $1 \%$ lignocaine,
$1 \mathrm{ml}$ and $2 \mathrm{ml}$ of $0.5 \%$ lignocaine and $2 \mathrm{ml}$ of $2 \%$ lignocaine were compared. ${ }^{37}$

Dexmedetomidine is a profoundly selective, specific and a potent $\alpha 2$ adrenoceptor agonist. It provides sedation, anxiolysis, analgesia and sympatholysis with supraspinal, spinal and peripheral activities. It has profound specificity for the $\alpha 2$ adrenoceptor $(\alpha 1 / \alpha 2 ; 1: 1600)$ compared to clonidine $(\alpha 1 / \alpha 2 ; 1: 200)$ making it a total agonist. It is metabolised in the liver and discharged in urine and faeces. ${ }^{38}$

Dexmedetomidine appears to relieve pain by altering the nociceptive (relating to pain arising from the stimulation of nerve cell) signal transmission at the central nervous system while additionally promoting peripheral anti-nociception. $\alpha 1$ $\alpha 2$ incitement may be a potential cause of central antinociception associated with alleviating propofol injection pain by causing the release of vasodilator prostaglandins which antagonise the vasoconstrictor reaction. This alters the reaction of venous smooth muscles and might be significant in endothelial dysfunction brought about by propofol.39 Mechanism of peripheral anti-nociception may be hyperpolarisation of afferent nerve fibres carrying pain sensations, however it has not yet been properly elucidated. 40 Dexmedetomidine also provides sedation and analgesia without causing depression of respiratory and the cardiovascular system.

This study was conducted to observe if injection dexmedetomidine is similar to or more effective in preventing propofol injection pain compared to injection lignocaine.

\section{METHODS}

This was a prospective, randomised and double blinded study conducted from 1 / 07 / 2018 to 31 / 07 / 2020 in Datta Meghe Institute of Medical Sciences, Sawangi, Wardha, Maharashtra, India. After acquiescence of the institutional ethics committee (DMIMS / IEC / 2018 - 19 / 7378), informed written consent of the patients was obtained.

An aggregate of 200 patients aged between 18 - 70 years, American Society of Anaesthesiologists grade I or II of both genders were planned for elective surgery under general anaesthesia using propofol as the chief induction agent were enrolled for the study. Patients aged below 18 years or above 70 years, patients with difficulty in communication, previous history of adverse effect to the study drugs, patients requiring rapid sequence induction and patients with anticipated difficulty in venous access were excluded from the study.

Patients were randomly allocated in two groups of 100 patients each using computer generated random number tables. Group I received i.v lignocaine $(0.2 \mathrm{mg} / \mathrm{Kg})$ diluted to $5 \mathrm{ml}$ with normal saline while group II received i.v dexmedetomidine $(0.5 \mathrm{mcg} / \mathrm{Kg})$ diluted to $5 \mathrm{ml}$ with normal saline.

Pre-anaesthetic check-up was performed on the patients planned for elective surgeries. Data including age, sex, weight, heart rate, non-invasive blood pressure and respiratory rate were collected.

Upon arrival in the operation room, a 20G cannula was secured on the non-dominant hand and electrocardiogram (ECG), pulse-oximeter and non-invasive blood pressure cuff were applied. Baseline values of vitals were measured and noted. 
An independent anaesthesiologist prepared the study drugs in $5 \mathrm{ml}$ syringes to make equal volumes by diluting with $0.9 \%$ normal saline. Both the study drugs were without additives and placed at room temperature. Blinding was ensured by excluding the anaesthesiologist who prepared the drugs during induction, pain assessment, follow up and analysis of data. The patients were also not involved in group distribution.

With the intention of keeping the experimentation drug within the vein, a pressure of $70 \mathrm{mmHg}$ was applied to the arm using a tourniquet to occlude the vein for 1 minute.

The investigation drugs were given through the cannula over 2 minutes. 1 minute after administration of the experimentation drugs, the tourniquet was released and $25 \%$ of the induction dose of i.v. propofol ( $2 \mathrm{mg} / \mathrm{Kg}$ ) was dispensed over 10 seconds, by a syringe.

Pain assessment was done during i.v propofol administration using the McCririck Hunter Scale. Patients were asked standard questions regarding the comfort of injection and were continuously observed for vocal response, frowning, arm withdrawal or tears suggesting severe pain. Pain was graded utilising a four-point scale: $0=$ no pain, $1=$ mild pain (patient complained of pain on questioning with absence of any behavioural signs), $2=$ moderate pain (patient complained of pain on questioning accompanied by behavioural signs or complained of pain without questioning), and 3 = severe pain (strong vocal reaction or reaction accompanied by frowning, withdrawal of arms or tearing of eyes).

Following assessment of pain, anaesthesia induction was accomplished with the remaining dose of propofol subsequently followed with muscle relaxant i.v vecuronium $(0.1 \mathrm{mg} / \mathrm{Kg})$ and tracheal intubation.

Anaesthesia was maintained with sevoflurane, vecuronium, nitrous oxide (50\%), oxygen (50\%) and controlled ventilation. Vitals including the heart rate, systolic, diastolic and mean arterial blood pressures were noted down at pre-induction, 2 minutes post intubation, 10 minutes post intubation and 10 minutes post extubation. The injection site was later checked for pain, erythema, wheal or flare within 24 hours following surgery.

\section{Statistical Analysis}

Statistical analysis was carried out using the program Statistical Package for Social Services (SPSS). The data was recorded as Mean $\pm \mathrm{SD}$, median and numbers (\%) as found suitable. Relationships between two categorical variables were tested using chi-square test. Two sample t-test were applied to compare normally distributed continuous variables between the two experimentation groups. P-value below 0.05 was contemplated as statistically significant.

Justification of sample size -

$\mathrm{n}=\frac{\left[(\mathrm{Z} \alpha / 2+\mathrm{Z} \beta)^{2} \mathrm{x}\{(\mathrm{p} 1(1-\mathrm{p} 1)+(\mathrm{p} 2(1-\mathrm{p} 2)\}]\right.}{(\mathrm{p} 1-\mathrm{p} 2)}$

Where,

$\mathrm{n}=$ sample size in each group

$\mathrm{p}^{1}=$ the proportion of patients relieved from propofol injection

pain by pre-treatment with injection lignocaine $=0.65$ $\mathrm{p}^{2}=$ the proportion of patients relieved from propofol injection pain by pre-treatment with injection dexmedetomidine $=0.45$ p1 - p2 = clinically significant difference $=0.65-0.45=0.2$

The values of $\mathrm{p} 1$ and $\mathrm{p} 2$ in the above formula were taken from the results published by $\mathrm{He} \mathrm{Y}$ et al. in their study "Comparison of lignocaine versus dexmedetomidine in preventing propofol induced injection pain during induction of general anaesthesia in Chinese patients undergoing gynaecologic surgery: a real-world evidence".

$\mathrm{Z} \alpha / 2=$ This depends on the level of significance, for $5 \%$ this is 1.96

$\mathrm{Z} \beta=$ This depends on power, for $80 \%$ this is 0.8

Based on the above formula, the minimum number of patients required in each study group is 93. Taking into account the number of dropouts, 100 patients were taken in each group.

\section{RESULTS}

This was a prospective, randomised and double-blinded study to compare the effectiveness and safety of prior intravenous dexmedetomidine with injection lignocaine as pre-treatment for prevention of propofol injection pain. An aggregate of 200 patients with 100 patients per group were studied.

\begin{tabular}{|c|c|c|c|c|c|}
\hline \multirow{2}{*}{$\begin{array}{c}\text { Class } \\
\text { Interval } \\
\text { (in yr.) }\end{array}$} & \multicolumn{2}{|c|}{$\begin{array}{l}\text { Group I (Lignocaine) } \\
\qquad(\mathrm{N}=100)\end{array}$} & \multicolumn{2}{|c|}{$\begin{array}{c}\text { Group II } \\
\text { (Dexmedetomidine) } \\
(\mathrm{N}=100)\end{array}$} & \multirow[t]{2}{*}{ P-Value } \\
\hline & $\begin{array}{c}\text { No. of } \\
\text { Patients }\end{array}$ & Mean \pm SD & $\begin{array}{c}\text { No. of } \\
\text { Patients }\end{array}$ & Mean \pm SD & \\
\hline $11-20$ & 6 & $41.21 \pm 14.72$ & 7 & $42.8 \pm 14.73$ & 0.446 (NS) \\
\hline $21-30$ & 25 & & 21 & & \\
\hline $31-40$ & 22 & & 23 & & \\
\hline $41-50$ & 17 & & 25 & & \\
\hline $51-60$ & 16 & & 12 & & \\
\hline $61-70$ & 13 & & 12 & & \\
\hline $71-80$ & 1 & & 0 & & \\
\hline Total & 100 & & 100 & & \\
\hline
\end{tabular}

Table 1 shows the distribution of patients in correspondence to their age. Their age ranged from 18 - 70 years in both the experimentation groups. There was no statistically significant difference between the two experimentation groups in correspondence to their age $(\mathrm{P}=$ 0.446). So, we assumed that the age distribution in the two groups were uniform and didn't influence the outcome of the study.

\begin{tabular}{|c|c|c|c|c|c|}
\hline \multirow{2}{*}{$\begin{array}{c}\text { Class } \\
\text { Interval } \\
\text { (in KG) }\end{array}$} & \multicolumn{2}{|c|}{$\begin{array}{c}\text { Group I Lignocaine } \\
\qquad(\mathrm{N}=100)\end{array}$} & \multicolumn{2}{|c|}{$\begin{array}{l}\text { Group II Dexmedetomidine } \\
\qquad(\mathrm{N}=100)\end{array}$} & \multirow{2}{*}{$\begin{array}{c}P \\
\text { Value }\end{array}$} \\
\hline & $\begin{array}{c}\text { No. of } \\
\text { Patient }\end{array}$ & $\begin{array}{l}\text { Mean } \pm \\
\text { SD }\end{array}$ & No. of Patient & Mean \pm SD & \\
\hline $41-50$ & 11 & & 12 & & \\
\hline $51-60$ & 26 & $64.13 \pm$ & 27 & $62.49 \pm$ & 0.235 \\
\hline $61-70$ & 33 & 10.02 & 37 & 9.46 & (NS) \\
\hline $71-80$ & 30 & & 24 & & \\
\hline Total & 100 & & 100 & & \\
\hline & Table & Body W & $\begin{array}{l}\text { of Patients Ac } \\
\text { ht in Kilogram. }\end{array}$ & ling to & \\
\hline
\end{tabular}

Table 2 shows the distribution of patients according to their body weight. The mean \pm SD weight of patients in group 
I was $64.13 \pm 10.02 \mathrm{Kg}$ and $62.49 \pm 9.46 \mathrm{Kg}$ in group II respectively.

Statistically, there were no notable distinctions between the experimentation groups in correspondence to their body weight $(\mathrm{P}=0.235)$. Thus, the weight distribution in the two experimentation groups was comparable and didn't influence the outcome of the study.

\begin{tabular}{|c|c|c|c|c|}
\hline $\begin{array}{l}\text { Grading of } \\
\text { Pain }\end{array}$ & $\begin{array}{c}\text { Group I } \\
(\mathrm{N}=100) \\
\text { Lignocaine }\end{array}$ & $\begin{array}{c}\text { Group II } \\
\text { Dexmedetomidine } \\
(\mathrm{N}=100)\end{array}$ & P-Value & $\begin{array}{c}\text { X2 } \\
\text { Value }\end{array}$ \\
\hline No pain & 62 & 80 & $0.0051(\mathrm{~S})^{*}$ & 1.746 \\
\hline Mild & 34 & 17 & $0.0059(\mathrm{~S})$ & 7.568 \\
\hline Moderate & 1 & 3 & $0.31(\mathrm{NS})^{* *}$ & 1.015 \\
\hline Severe & 3 & 0 & - & - \\
\hline Total & 100 & 100 & & \\
\hline \multicolumn{5}{|c|}{$\begin{array}{c}\text { Table 3. Distribution of Pain during Propofol Injection } \\
\text { in the Study Groups }\end{array}$} \\
\hline
\end{tabular}

Table 3 shows the comparison of pain in the experimentation groups during administration of i.v propofol. $62 \%$ patients in group 1 (i.v lignocaine) had no complaints of pain during i.v propofol administration whereas $80 \%$ patients in group II (i.v dexmedetomidine) experienced no pain, which was statistically significant.

Mild pain was perceived by $34 \%$ patients in group I and $17 \%$ in group II respectively, which was statistically significant. Patients with moderate pain in group I and group II were $1 \%$ and $3 \%$ respectively, which was statistically nonsignificant. Severe pain was perceived by $3 \%$ patients in group I while patients in group II had no incidence of severe pain.

\begin{tabular}{|c|c|c|c|}
\hline $\begin{array}{l}\text { Mean Arterial } \\
\text { Pressure (mm } \\
\text { of } \mathbf{H g})\end{array}$ & $\begin{array}{c}\text { Group1 } \\
\text { (Lignocaine) } \\
\mathrm{N}=100\end{array}$ & $\begin{array}{c}\text { Group } 2 \\
\text { (Dexmedetomidine) } \\
\mathrm{N}=\mathbf{1 0 0}\end{array}$ & P-Value \\
\hline Baseline & $95.26 \pm 11.86$ & $94.73 \pm 11.33$ & 0.745 (NS)* \\
\hline Pre / at induction & $92.17 \pm 10.54$ & $91.48 \pm 11.12$ & 0.653 (NS) \\
\hline $\begin{array}{l}2 \text { minutes after } \\
\text { intubation }\end{array}$ & $120.93 \pm 5.61$ & $120.14 \pm 5.14$ & $0.3004(\mathrm{NS})$ \\
\hline $\begin{array}{l}10 \text { minutes after } \\
\text { intubation }\end{array}$ & $105.39 \pm 6.43$ & $104.37 \pm 6.22$ & 0.255 (NS) \\
\hline $\begin{array}{l}10 \text { minutes after } \\
\text { extubation }\end{array}$ & $102.15 \pm 7.27$ & $101.65 \pm 7.19$ & 0.625 (NS) \\
\hline \multicolumn{4}{|c|}{$\begin{array}{l}\text { Table 4. Correlation of Mean Arterial Pressure between the Two } \\
\text { Experimentation Groups at Different Time Periods }\end{array}$} \\
\hline
\end{tabular}

Table 4 shows the correlation of mean arterial pressure between the experimentation groups at distinct time periods. The patients in the two experimentation groups were comparable based on baseline mean arterial pressure measured pre-operatively $(\mathrm{P}=0.745)$. The difference between the groups were statistically non-significant in correspondence to mean arterial pressure at different time periods $(\mathrm{P}>0.05)$.

Table 5 shows the correlation of mean heart rate at distinct time spans in between the two groups. The patients in both groups were comparable in correlation to baseline heart rate measured pre-operatively $(\mathrm{P}=0.943)$.

The difference between the groups were statistically nonsignificant in correlation to heart rate measured at distinct time spans $(\mathrm{P}>0.05)$ except at 10 minutes post intubation where the heart rate was outstandingly low in group II compared to group I $(\mathrm{P}=0.05)$.

\begin{tabular}{|c|c|c|c|}
\hline $\begin{array}{l}\text { Mean Heart Rate } \\
\text { (Beats / Minute) }\end{array}$ & $\begin{array}{c}\text { Group1 } \\
\text { (Lignocaine) } \\
\mathbf{N}=100\end{array}$ & $\begin{array}{c}\text { Group } 2 \\
\text { (Dexmedetomidine) } \\
\mathbf{N}=100\end{array}$ & P-Value \\
\hline Baseline & $81.93 \pm 6.83$ & $81.86 \pm 7.13$ & $0.943(\mathrm{NS})^{*}$ \\
\hline Pre / at induction & $80.88 \pm 6.61$ & $79.53 \pm 6.94$ & 0.160 (NS) \\
\hline 2 minutes after intubation & $108.66 \pm 8.82$ & $107.42 \pm 7.94$ & 0.297 (NS) \\
\hline 10 minutes after intubation & $90.47 \pm 7.02$ & $88.48 \pm 7.54$ & $0.054(S)^{* *}$ \\
\hline 10 minutes after extubation & $88.96 \pm 6.50$ & $87.70 \pm 6.49$ & 0.171 (NS) \\
\hline \multicolumn{4}{|c|}{$\begin{array}{l}\text { Table 5. Correlation of Heart Rate between } \\
\text { the Two Groups at Distinct Time Intervals }\end{array}$} \\
\hline$\therefore$ c & & & \\
\hline
\end{tabular}

\section{DISCUSSION}

Propofol is a phenomenal intravenous anaesthetic classified under the group of phenols with a propensity of causing irritation of the skin, mucous membrane and venous intima. The major downside of propofol is the pain following its injection with an incidence between $24-70 \% 1,2$ and it is ranked seventh in order of frequency and clinical importance. ${ }^{3}$

Several authors have contemplated the mechanisms and strategies for lessening pain during i.v propofol administration. Nakane and Iwama ${ }^{6}$ reported that the lipid base of propofol activated the kallikrein-kinin system and produced bradykinin which modified the local vein. This alteration of the peripheral vein enhances the exposure of the sensitive ends of peripheral nerves present in the walls of the blood vessels to the aqueous phase propofol, thereby worsening the propofol instigated pain. They conducted distinct studies using nafamostat mesilate, a kailikrein inhibitor or lignocaine and arrived at the conclusion that bradykinin was completely inhibited by nafamostat and lignocaine. $10 \mathrm{mg} / \mathrm{Kg}$ i.v propofol was administered in our investigation. Mangar D and Holak EJ ${ }^{27}$ reported that administration of i.v lignocaine $2 \%$ following a tourniquet inflation of $50 \mathrm{~mm}$ of $\mathrm{Hg}$ pressure subsequently followed $1 \mathrm{~min}$ later by propofol (2 $\mathrm{mg} / \mathrm{Kg}$ ) injection nullified the pain accompanying i.v propofol administration. Applying a tourniquet permitted more contact time for lignocaine and the nerve endings of peripheral fibres, subsequently, lessening the pain on i.v propofol administration. In our investigation, venous impediment for 1 minute after administration of experimentation drugs using a tourniquet pressure of 70 mmHg was done before administration of propofol. Lignocaine concentration played a significant role in diminishing propofol instigated pain. He et al. ${ }^{18}$ conducted a study contrasting the influence of intravenous $2 \%$ lignocaine $(0.2 \mathrm{mg} / \mathrm{Kg})$ and intravenous dexmedetomidine $(0.2 \mathrm{mcg} / \mathrm{Kg})$ in preventing propofol instigated pain and they found that $65 \%$ patients given i.v lignocaine had no pain accompanying propofol administration which was remarkably higher compared to dexmedetomidine which had $45 \%$. Based on their observations, we used i.v lignocaine concentration of $2 \%$ at $0.2 \mathrm{mg} / \mathrm{Kg}$ in our investigation.

Dexmedetomidine is an extremely selective, specific and potent adrenoceptor agonist with additional properties of analgesia, sedation, anxiolysis and sympatholytic actions. $\alpha 2$ adrenoceptors located in the blood vessels inhibit norepinephrine release and promote the release of vasodilator prostaglandins that antagonise the vasoconstrictor response. Dexmedetomidine is also hypothesised to promote peripheral anti-nociception through hyperpolarisation of pain 
conducting peripheral afferent nerve fibres though it has not been precisely elucidated. Jeong Han Lee et al. ${ }^{19}$ enacted a study in which they randomly divided 160 patients into 4 groups; group 1 received propofol $120 \mathrm{mg}$ and normal saline $(\mathrm{N}=40)$, group 2 received propofol $120 \mathrm{mg}$ and dexmedetomidine $0.25 \mathrm{mcg} / \mathrm{Kg}(\mathrm{N}=40)$, group 3 received propofol $120 \mathrm{mg}$ and dexmedetomidine $0.5 \mathrm{mcg} / \mathrm{Kg}(\mathrm{N}=40)$ and group 4 received propofol $120 \mathrm{mg}$ and dexmedetomidine $0.75 \mathrm{mcg} / \mathrm{Kg}(\mathrm{N}=40)$. They reported that $0.5 \mathrm{mcg} / \mathrm{Kg}$ dexmedetomidine blended with propofol is the proper dosage for relieving pain on administration and for maintaining haemodynamic stability. Based on their observations, $0.5 \mathrm{mcg}$ / Kg intravenous dexmedetomidine was provided as pretreatment, 1 minute prior to i.v propofol administration in our investigation.

The main finding of our study was that the utilisation of dexmedetomidine given as intravenous pre-treatment of 0.5 $\mathrm{mcg} / \mathrm{Kg}$ by applying tourniquet pressure of $70 \mathrm{mmHg}$ on the arm for venous impediment was more efficacious in lessening the pain accompanying i.v propofol administration compared to $2 \%$ i.v lignocaine given $0.2 \mathrm{mg} / \mathrm{Kg}$. $80 \%$ patients in dexmedetomidine group did not perceive any pain during the course of i.v propofol administration compared to $62 \%$ in the lignocaine group which was statistically significant $(\mathrm{P}=$ 0.005). Our study was comparable to Aditya et al. ${ }^{41}$ who concluded that prior treatment with i.v dexmedetomidine given $0.2 \mathrm{mcg} / \mathrm{Kg}$ by applying tourniquet pressure for $1 \mathrm{~min}$ on the ipsilateral arm before inducing the patient with propofol was more effective in decreasing the pain accompanying i.v propofol administration in comparison to preservative-free $0.5 \mathrm{mg} / \mathrm{Kg}$ i.v lignocaine and placebo. 1 minute after the administration of propofol, $0 \%$ patients in dexmedetomidine group and $70 \%$ patients in lignocaine group had episodes of pain. A remarkable diminution in pain score at $1 \mathrm{~min}$ of dispensing i.v propofol in the dexmedetomidine group was noticed in their study $(\mathrm{P}<$ 0.0001).

\section{CONCLUSIONS}

Pre-treatment with dexmedetomidine $0.5 \mathrm{mcg} / \mathrm{Kg}$ with venous occlusion for one minute is more effective compared to intravenous lignocaine as a pre-treatment in alleviating propofol injection pain along with significantly better haemodynamic stability following laryngoscopy and intubation and may be a useful alternative for reducing pain on propofol injection. Dexmedetomidine also has additional properties of sedation and anxiolysis which gives the anaesthesiologist an added advantage.

\section{Limitations}

The chief drawback of the study is the lack of a standardised protocol to prevent hypotension or bradycardia perioperatively. Pre-loading technique hasn't been clearly defined. The experimentation drugs were injected over 2 minutes, though several authors differ in their perspective concerning the rate of infusion. It would have been more accurate to dispense the drugs by an "electronic syringe pump" rather than administering them manually.
Data sharing statement provided by the authors is available with the full text of this article at jemds.com.

Financial or other competing interests: None.

Disclosure forms provided by the authors are available with the full text of this article at jemds.com.

\section{REFERENCES}

[1] Fuji Y, Itakura M. Comparison of lignocaine, metoclopramide and flurbiprofen axetil for reducing pain on injection of propofol in Japanese adult surgical patient: a prospective, randomised, double blind, parallel group, placebo-controlled study. Clin Ther 2008;30(2):280-6.

[2] Picard P, Tramer MR. Prevention of pain on injection with propofol: a quantitative systematic review. Anesth Analg 2000;90(4):963-9.

[3] Macario A, Weinger M, Truong $P$, et al. Which clinical anesthesia outcomes are both common and important to avoid? The perspective of a panel of expert anesthesiologists. Anesth Analg 1999;88(5):1085-91.

[4] Ambesh SP, Dubey PK, Sinha PK. Ondansetron pretreatment to alleviate pain on propofol injection: a randomized, controlled, double-blinded study. Anesth Analg 1999;89(1):197-9.

[5] Scott RP, Saunders DA, Norman J. Propofol: clinical strategies for preventing the pain of injection. Anaesthesia 1998;43(6):492-4.

[6] Nakane M, Iwama H. A potential mechanism of propofolinduced pain on injection based on studies using nafamostat mesilate. Br J Anaesth 1999;83(3):397-404.

[7] Matta JA, Cornett PM, Miyares RL, et al. General anesthetics activate a nociceptive ion channel to enhance pain and inflammation. Proc Natl Acad Sci U S A 2008;105(25):8784-9.

[8] Fischer MJM, Leffler A, Niedermirt F, et al. The general anesthetic propofol excites nociceptors by activating TRPV1 and TRPA1 rather than GABAA Receptors. J Biol Chem 2010;2859(45):34781-92.

[9] Agarwal A, Raza M, Dhiraaj S, et al. Pain during injection of propofol: the effect of prior administration of butorphanol. Anesth Analg 2004;99(1):117-9.

[10] Lyons B, Lohan D, Flynn C, et al. Modification of pain on injection of propofol. A comparison of pethidine and lignocaine. Anaesthesia 1996;51(4):394-5.

[11] Canbay 0, Celebi N, Arun O, et al. Efficacy of intravenous acetaminophen and lignocaine on propofol injection pain. Br J Anaesth 2008;100(1):95-8.

[12] Pang WW, Huang PY, Chang DP, et al. The peripheral analgesic effect of tramadol in reducing propofol injection pain: a comparison with lignocaine. Reg Anaesth Pain Med 1999;24(3):246-9.

[13] Koo SW, Cho SJ, Kim YK, et al. Small-dose ketamine reduces the pain of propofol injection. Anesth Analg 2006;103(6):1444-7.

[14] Agarwal A, Ansari MF, Gupta D, et al. Pretreatment with thiopental for prevention of pain associated with propofol injection. Anesth Analg 2004;98(3):683-6.

[15] Azma T, Kawai K, Tamura H, et al. Comparative benefit of preemptively applied thiopental for propofol injection pain: the advantage over lidocaine. Hiroshima J Med Sci 2004;53(1):13-6. 
[16] Ganta R, Fee JP. Pain on injection of propofol: comparison of lignocaine and metoclopramide. $\mathrm{Br} \mathrm{J}$ Anaesth 1992;69(3):316-7.

[17] Cheong MA, Kim KS, Choi WJ. Ephedrine reduces the pain from propofol injection. Anesth Analg 2002;95(5):12936.

[18] He Y, Li D, Tan Z. Comparison of lignocaine versus dexmedetomidine in preventing propofol induced injection pain during induction of general anaesthesiain Chinese patient undergoing gynaecologic surgery: real world evidence. Biomedical Research 2017;28(4):1890-3.

[19] Lee JH, Jung SY, Kim MH, et al. The effect of dexmedetomidine on propofol injection pain. Korean J Anaesthesiol 2014;67(Suppl):S30-1.

[20] Uzun S, Kose EA, Karagoz AH, et al. Dexmedetomidine for prevention of propofol injection pain. Anaesthesia 2008;24(4):406-8.

[21] Ayoglu H, Altunkaya H, Ozer Y, et al. Does dexmedetomidine reduce the injection pain due to propofol and rocuromum. Eur J Anaesthesiol 2007;24(6):541-5.

[22] Sarkilar G, Kara I, Duman A, et al. Effect of Dexmedetomidine on pain caused by injection of propofol. Nobel Med 2012;8(1):83-8.

[23] Barker P, Langton JA, Murphy P, et al. Effect of prior administration of cold saline during propofol injection. A comparison with cold propofol and propofol with lignocaine. Anaesthesia 1991;46(12):1069-70.

[24] Cameron E, Johnston G, Crofts S, et al. The minimum effective dose of lignocaine to prevent injection pain due to propofol in children. Anaesthesia 1992;47(7):604-6.

[25] Tsubokura H, Inagaki Y, Adachi $H$, et al. Efficacy of simultaneous bolus injection of lignocaine with propofol on pain caused by propofol injection. Masui 2001;50(11):1196-200.

[26] Lee P, Russel WJ. Preventing pain on injection of propofol: a comparison between lignocaine pre-treatment and lignocaine added to propofol. Anaesth Intensive Care 2004;32(4):482-4.

[27] Mangar D, Holak EJ. Tomiquet at $50 \mathrm{mmHg}$ followed by intravenous lignocaine diminishes hand pain associated with propofol injection. Anesth Analg 1992;74(2):250-2.

[28] Ho CM, Tsou MY, Sun MS, et al. The optimal effective concentration of lignocaine to reduce pain on injection of propofol. J Clin Anesth 1999;11(4):296-300.
[29] Sen H, All S, Omer Y, et al. The effects of propofol concentration on propofol injection pain. Anatol J 2009;3(2):127-30.

[30] McCrirrick A, Hunter S. Pain on injection of propofol: the effect of injectate temperature. Anaesthesia 1990;45(6):443-4.

[31] Stokes DN, Robson N, Hutton P. Effect of diluting propofol on the incidence of pain on injection and venous sequelae. Br J Anaesth 1989;62(2):202-3.

[32] O'Hara JR, Sprung J, Laseter JT, et al. Effects of topical nitroglycerin and intravenous lignocaine on propofolinduced pain on injection. Anesth Analg 1997;84(4):8659.

[33] Nathanson MH, Gajraj NM, Russel JA. Prevention of pain on injection of propofol: a comparison of lignocaine with alfentanil. Anesth Analg 1996;82(3):469-71.

[34] King SY, Davis FM, Wells JE, et al. Lignocaine for the prevention of gain due to injection of propofol. Anesth Analg 1992;74(2):246-9.

[35] Overbaugh R, Jone P, Nguyen A, et al. Effect of mixed versus unmixed lignocaine with propofol. Internet Anesthesiol 2003;7(2):33.

[36] Tan LH, Hwang NC. The effect of mixing lignocaine with propofol on the dose of propofol required for induction of anesthesia. Anesth Analg 2003;97(2):461-4.

[37] Adachi $\mathrm{H}$, Inagaki $\mathrm{Y}$, Harada $\mathrm{T}$, et al. Effects of concentration and dosage of lignocaine on preventing the pain of injection of propofol. Masui 2002;51(9):983-7.

[38] Takahiko K, Mervyn M. Clinical uses of alpha2 - adrenergic agonists. Anesthesiology 2000;93(5):1345-9.

[39] Callow ID, Campisi P, Lambert ML, et al. Enhanced in vivo alpha 1 and alpha 2 adrenoceptor mediated venoconstriction with indomethacin in humans. Am J Physiol 1998;275(3):H837-43.

[40] Dalle C, Schneider M, Clergue F, et al. Inhibition of the I(h) current in isolated peripheral nerve: a novel mode of peripheral antinociception? Muscle Nerve 2001;24(2):254-61.

[41] Aditya K, Reddy AKS, Rao MH. Comparison of intravenous dexmedetomidine and intravenous lignocaine for the prevention of conventional propofol injection pain: a prospective randomised double-blind study. Journal of Clinical and Scientific Research 2018;7(4):170-4. 